\title{
Effects of Rotigaptide and RIC on Ischemia Reperfusion Injury in the In Vitro Rabbit Heart
}

\author{
Salman $\mathbf{R}^{1}$, Johnsen $\mathbf{J}^{\mathbf{1}}$, Lassen TR ${ }^{1}$, Hansen $\mathbf{R S}^{2}$, Bøtker HE ${ }^{1}$ and Schmidt $\mathbf{M R}^{1 *}$ \\ ${ }^{1}$ Department of Cardiology, Aarhus University Hospital, 8000 Aarhus N, Denmark \\ 'Zealand Pharma A/S, Smedeland 36, 2600 Glostrup, Denmark
}

\begin{abstract}
Background: Remote Ischemic Preconditioning (rIPC) and the antiarrhythmic peptide analogue, Rotigaptide (ZP123), protects against myocardial ischemia-reperfusion injury through potentially similar mechanisms. We aimed to study whether the cardioprotective effects of Rotigaptide and rIPC interacts.

Methods: We used male New Zealand White rabbit hearts mounted in a Langendorff system and exposed to $30 \mathrm{~min}$ of global no-flow ischemia and $120 \mathrm{~min}$ of reperfusion. A total of 48 rabbits were randomized into 6 groups: control $(n=6)$, Rotigaptide $(1 \mu M)$ before $(n=9)$ or after $(n=9)$ ischemia, rIPC $(n=7)$, rlPC+Rotigaptide before $(n=9)$ or after $(n=8)$ ischemia. rIPC was induced by four cycles of 5 -min ischemia and reperfusion on the left hind limb achieved by intermittent tourniquet occlusion. Primary endpoint was infarct size measured by tetrazolium staining.

Results: rIPC reduced infarct size compared to controls. Rotigaptide alone did not affect infarct size irrespective of administration before ischemia or during reperfusion. The combination of rIPC and Rotigaptide before ischemia reduced infarct size, whereas the effect of rIPC was abrogated by Rotigaptide when administered during reperfusion. No significant changes in hemodynamic recovery were observed when compared to control group.

Conclusion: In contrast to in vivo rIPC, in vitro Rotigaptide did not yield cardioprotection in our rabbit model, but Rotigaptide attenuated the effect of rIPC. These findings indicate that modification of myocardial gap junction is involved in cardioprotection by rIPC.
\end{abstract}

Keywords: Ischemia; Reperfusion; Myocardial infarction; Connexin 43; Rotigaptide; Remote ischemic

\section{Introduction}

Early revascularization is paramount to salvage threatened myocardium in ST-Elevation Myocardial Infarction (STEMI). Paradoxically, reperfusion itself may cause myocardial damage beyond the ischemic damage. Combined acute ischemia and reperfusion injury may lead to irreversible tissue injury and cell death and determines final infarct size. Protecting the heart beyond the myocardial salvage achieved by early revascularization is crucial as infarct size is directly linked to patient outcome [1].

One of the most promising concepts of cardioprotection in the clinical setting is Remote Ischemic Preconditioning (rIPC), which can be achieved by repeated periods of non-lethal ischemia and reperfusion in a distant organ or body part, e.g. a limb, before a sustained ischemic insult to the target organ. When applied during an evolving myocardial infarction, rIPC reduces troponin release [27] and increases myocardial salvage in patients admitted with STEMI admitted for Primary Percutaneous Coronary Intervention (pPCI) [8]. An alternative cardioprotective approach is pharmacological conditioning. Multiple pharmacological compounds have been shown to exert cardioprotection in animal models but the majority have failed to translate successfully into beneficial effect in clinical studies [9]. However, most of these drugs target only one of many signalling pathways involved in cardioprotection and do not fully replicate ischemic preconditioning, which may explain the absent success in clinical trials.

Rotigaptide reduces infarct size in experimental models of myocardial ischemia-reperfusion injury [10-12] Rotigaptide has been demonstrated to prevent dephosphorylation of $\mathrm{Cx} 43$ during ischemic stress [13]. Sarcolemmal Cx43 contributes to the dissemination of myocardial injury $[14,15]$ and inhibition of sarcolemmal Cx43 is cardioprotective [16,17]. Cx43 is also present in mitochondria and, in contrast to sarcolemmal Cx43, opening of mitochondrial $\mathrm{Cx} 43$ channels before ischemia/reperfusion provides protection against ischemia/reperfusion injury by ischemic preconditioning [18]. Modulation of $\mathrm{Cx} 43$ protein expression and phosphorylation also seem to be an inherent component of rIPC [19], suggesting that Rotigaptide and rIPC may interact such that the effect of simultaneosus administration may provide information about the mechanisms underlying rIPC.

The aim of the present study was to investigate the individual cardioprotective efficacy of Rotigaptide and rIPC and whether they have interacting cardioprotective effects against ischemia-reperfusion injury in rabbit model.

\section{Materials and Methods}

Adult male New Zealand White rabbits $(2.5-3.6 \mathrm{~kg})(\mathrm{n}=48)$ were handled in accordance with institutional and national guidelines for animal research, The Animal Experiments Inspectorate in Denmark (Dyreforsøgstilsynet, Copenhagen, Denmark).

*Corresponding author: Michael Rahbek Schmidt, Department of Cardiology, Aarhus University Hospital, Palle Juul-Jensens Boulevard 99, 8200 Aarhus N Denmark, Tel: 00457845 2262; Fax: +45 78452260; E-mail: rahbek@dadlnet.dk

Received April 06, 2017; Accepted April 25, 2017; Published April 29, 2017

Citation: Salman R, Johnsen J, Lassen TR, Hansen RS, Bøtker HE, et al. (2017) Effects of Rotigaptide and RIC on Ischemia Reperfusion Injury in the In Vitro Rabbit Heart. Cardiovasc Pharm Open Access 6: 209. doi: 10.4172/2329-6607.1000209

Copyright: ( 2017 Salman R, et al. This is an open-access article distributed under the terms of the Creative Commons Attribution License, which permits unrestricted use, distribution, and reproduction in any medium, provided the original author and source are credited. 


\section{Study groups}

Animals were randomized into six different groups (Figure $1)$, control $(n=6)$ and $\operatorname{rIPC}(n=7)$, Rotigaptide before ischemia or immediately at the onset of reperfusion (PreRoti, $n=9$ or PostRoti, $\mathrm{n}=9$ ), or a combination of rIPC and Rotigaptide before ischemia or during reperfusion (PreRotirIPC, $\mathrm{n}=9$ or PostRotirIPC, $\mathrm{n}=8$ ).

After in vivo rIPC or a time-matched sham procedure according to protocol, the heart was excised. The isolated hearts were subjected to 20 min of stabilization, 10 min of Rotigaptide or vehicle administration, $30 \mathrm{~min}$ of global no-flow ischemia, and $120 \mathrm{~min}$ of reperfusion $(2 \mathrm{~h})$, a total of $180 \mathrm{~min}$.

\section{Experimental preparation}

Peripheral intravenous access was obtained through a marginal ear vein. Anaesthesia was induced by a bolus of sodium pentobarbital $(30 \mathrm{mg} / \mathrm{kg}$ ). The rabbits were weighed and placed over a heat pad. Anaesthesia was maintained by a continuous infusion of $50 \mathrm{mg} / \mathrm{h}$ of sodium pentobarbital. When adequate depth of anaesthesia was obtained as evaluated by loss of the toe pinch reflex, a tracheostomy was performed and the rabbit was immediately connected to a volumecontrolled ventilator (Ugo Basile 7025 rodent ventilator, Comerio, Italy). Arterial blood samples (Radiometer ABL700-serie) were taken from the central ear artery to assure appropriate ventilation and oxygenation.

A laparotomy and thoracotomy was performed. The animals were heparinized by a bolus of $100 \mathrm{IU} / \mathrm{kg}$ heparin i.v. (Leo Pharma, Copenhagen, Denmark) prior to cannulation. A thymectomy and excision of the pericardium and surrounding tissue was performed to reveal the aorta. A tourniquet was placed around the ascending aorta. The ascending aorta was cannulated with the heart in-situ, the tourniquet was tightened and retrograde perfusion with KrebsHenseleit $(\mathrm{KH})$ buffer was immediately commenced. The heart was then rapidly excised and mounted on the ex-vivo, Langendorff apparatus (Hugo Sachs Elektronik, Harvard Apparatus). The hearts were continuously retrogradely perfused at a constant pressure of 70 $\mathrm{mmHg}$ with $\mathrm{KH}$ buffer $\left(118.5 \mathrm{mM} \mathrm{NaCl} ; 25.0 \mathrm{mM} \mathrm{NaHCO}_{3} ; 11.1\right.$ $\mathrm{mM}$ glucosemonohydrate; $1.2 \mathrm{mM} \mathrm{MgSO} ; 2.0 \mathrm{mM} \mathrm{CaCl}_{2} ; 1.2 \mathrm{mM}$ $\mathrm{KH}_{2} \mathrm{PO}_{4} ; 4.7 \mathrm{mM} \mathrm{KCl}$ ) at $37.0^{\circ} \mathrm{C}$ oxygenated with $95 \% \mathrm{O}_{2}$ and $5 \% \mathrm{CO}_{2}$ to maintain a pH level of 7.35-7.45. Once the heart was mounted on the Langendorff setting, excess connective tissue and fat was excised and aorta was secured with additional ligatures to maintain an adequate coronary flow. An incision was made in the left atrial auricle where a balloon-tipped catheter (size 14, Hugo Sachs Electronics, MarchHugstetten, Germany) connected to a pressure transducer was inserted into the left ventricular cavity to allow for continuous measurements of the heart rate, diastolic and systolic pressure. The diastolic pressure was set to $7-12 \mathrm{mmHg}$ by adjusting the balloon volume during stabilization. Hearts were submerged in a custom made preheated glass-cup to keep the myocardium at constant $37.0^{\circ} \mathrm{C}$

Coronary flow was measured continuously by an inline flow meter (Hugo Sachs Electronics, March-Hugstetten, Germany). Hemodynamic data and coronary flow measurements were acquired using a dedicated software platform (Notocord, Croissy sur Seine, France).

\section{Cx43 modification}

Rotigaptide was synthesized and supplied by Zealand Pharma. An effluent sample was acquired at the end of reperfusion for each Rotigaptide-protocol from sixteen random experiments after pre- and post-ischemic Rotigaptide administration. The samples were frozen at $-80^{\circ} \mathrm{C}$ and subsequently analysed for verification of the target concentration in buffer solution during reperfusion.

\section{Remote ischemic preconditioning}

In vivo rIPC was performed using an occluding tourniquet on the left hind limb. Distal limb pallor was observed during occlusion of the arterial blood flow followed by reactive hyperaemia during reperfusion. Ultra-high frequency ultrasound (Vevo ${ }^{\circ} 2100$, VisualSonics Inc., Toronto, ON, Canada) with a $32-56 \mathrm{MHz}$ linear array transducer was furthermore used to confirm occlusion in selected animals). rIPC was performed in anaesthetized animals as 4 cycles of $5 \mathrm{~min}$ of ischemia followed by $5 \mathrm{~min}$ of reperfusion followed by an additional $15 \mathrm{~min}$ of rest separating the rIPC procedure and the heart explant. During the rIPC protocol, adequate depth of anaesthesia, ventilation and stable body temperature was maintained. Control animals underwent the same procedure but the tourniquet was not tightened.

Infarct size: Immediately after the end of the perfusion protocol, the hearts were removed from the Langendorff apparatus, frozen at $-80^{\circ} \mathrm{C}$ and manually sliced into approximately $1.5 \mathrm{~mm}$ slices. The slices were placed in individual tissue cassettes and incubated into a solution of 1\% 2,3,5-Triphenyltetrazolium Chloride (TTC), (Sigma, St. Louis, Mo, USA) at $37^{\circ} \mathrm{C}$ for $5 \mathrm{~min}$. The cassettes were then immersed in ice-cold water to discontinue the staining procedure and stored in

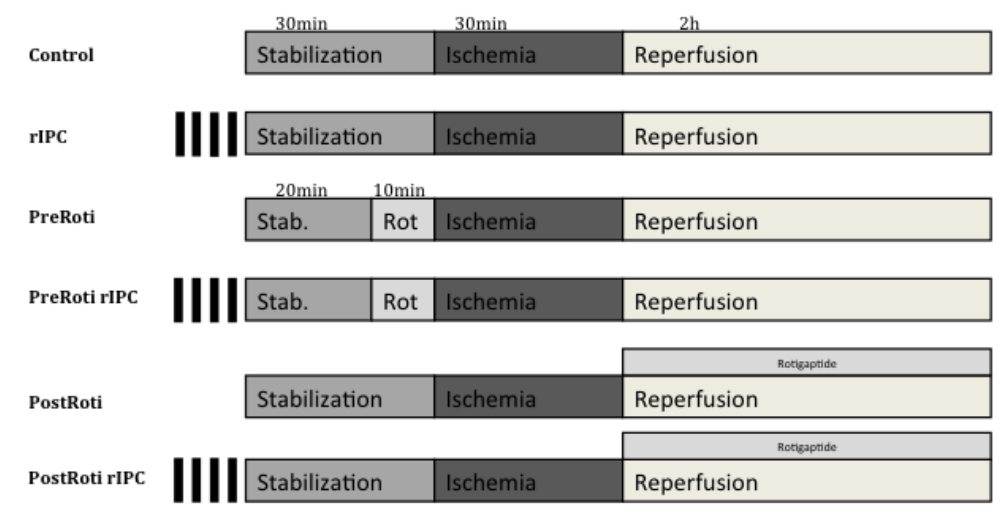

Figure 1: Study protocols: Displaying the protocols used in each group. rIPC: Remote ischemic preconditioning; PreRoti: Rotigaptide before ischemia; PreRotirlPC: Rotigaptide before ischemia+remote ischemic preconditioning; PostRoti: Rotigaptide after ischemia; PostRotirlPC: Rotigaptide after reperfusion+remote ischemic preconditioning. 
$4 \%$ formaldehyde solution overnight to enhance the vital from the infarcted area. The following day the slices were weighed and scanned in a flatbed scanner (Canon, $9000 \mathrm{~F}$ Mark II). Manual delineating the area of the left ventricle which is equal to the Area-at-Risk (AAR) in our global ischemia model and delineation of the area of the infarcted tissue was performed using image analysing software (Image J, NIH). Measurements were weighted with the mass of each individual slice and the infarct size/area-at-risk ratio (IS/AAR) was calculated. All tracings were executed by a single investigator and in a blinded manner.

Statistics: All statistical data are presented as mean \pm SEM. IS was analysed using one-way Analysis of Variance (ANOVA) followed by Bonferroni's post hoc test. Hemodynamic data were compared using two-way ANOVA with repeated measurements followed by Dunnett's post hoc test. Left Ventricular Developed Pressure (LVDP) was calculated by subtracting the LV diastolic pressure from the LV systolic pressure. One-way ANOVA was used to compare LVDP, Rate Pressure Product (RPP), Heart Rate, Coronary Flow (CF) and $\mathrm{dP} / \mathrm{dt}$ max at specific timepoints. $\mathrm{P}<0.05$ was considered statistically significant. Statistical analyses were performed using GraphPad Prism6 (GraphPad Software Inc., San Diego, CA, USA).

\section{Results}

\section{Infarct size}

rIPC reduced Infarct Size (IS) compared to controls $(32.7 \pm 5.9$ vs. $64.2 \pm 4.9 \%, \mathrm{p}=0.0002)$. Rotigaptide alone administered prior to (PreRoti) or after (PostRoti) ischemia had no effect on IS ( $p>0.99)$. The combination of rIPC and Rotigaptide prior to ischemia (PreRotirIPC) reduced IS compared to controls $(45.4 \pm 3.3$ vs. $64.2 \pm 4.9 \%, \mathrm{p}=0.04)$, although IS was insignificantly higher than rIPC alone ( $45.4 \pm 3.3$ vs. $32.7 \pm 5.9 \%, \mathrm{p}=0.31$ ) suggesting an attenuation of the cardioprotective signal when administered before ischemia (Figure 2). We found no IS reduction by rIPC when Rotigaptide was administered during reperfusion (PostRotirIPC) as compared to controls (52.0 \pm 5.9 vs. $64.2 \pm 4.9 \%, \mathrm{p}=0.49)$. Notably, this group had significantly larger infarcts than the group receiving rIPC alone ( $52.0 \pm 5.9$ vs. $32.7 \pm 5.9 \%$, $\mathrm{p}=0.027$ ) (Figure 2).

\section{Hemodynamic recovery}

The rIPC-group tended towards a better hemodynamic recovery of LVDP, RPP and $\mathrm{dP} / \mathrm{dt}$ max although differences between groups were not significant (Table 1). Rotigaptide before ischemia or after reperfusion with rIPC (PreRotirIPC and PostRotirIPC) or without rIPC (PreRoti and PostRoti) did not improve hemodynamic recovery when compared to control (Table 1). Notably, when compared to rIPC alone, recovery of LVDP in the PostRotirIPC group was decreased with statistically borderline significance $(17.8 \pm 1.3$ vs. $30.0 \pm 2.0 \mathrm{mmHg}$, $\mathrm{p}=0.06$ ).

\section{Rotigaptide concentrations}

Mean concentrations of Rotigaptide in the perfusate after administration were: rIPC: below detection limit, preischemic administration: $0.13 \pm 0.12$ (range 0-0.53) $\mathrm{nmol} / \mathrm{l} \quad(\mathrm{n}=9)$ and postischemic administration: $200 \pm 26$ (range 100-283) $\mathrm{nmol} / \mathrm{l}(\mathrm{n}=7)$.

\section{Discussion}

The main result of the present study is that Rotigaptide exerts no significant cardioprotective effect in our isolated rabbit heart model of ischemia and reperfusion injury. In addition, Rotigaptide seems to attenuate the cardioprotective effect of rIPC when administered before ischemia and abrogate the cardioprotective effect of rIPC when administered during reperfusion. These finding may indicate that modification of gap junctions with a predominant increment of gap junction intercellular communication at reperfusion may promote expansion of irreversible injury and hence attenuate the cardioprotective effect of rIPC.

Our results are in contrast to our previous experience in an in vivo pig model of catheter-induced occlusion of the left anterior descending artery [10]. We demonstrated a significant $57 \%$ IS reduction following

\section{Infarct size/ Area at risk}

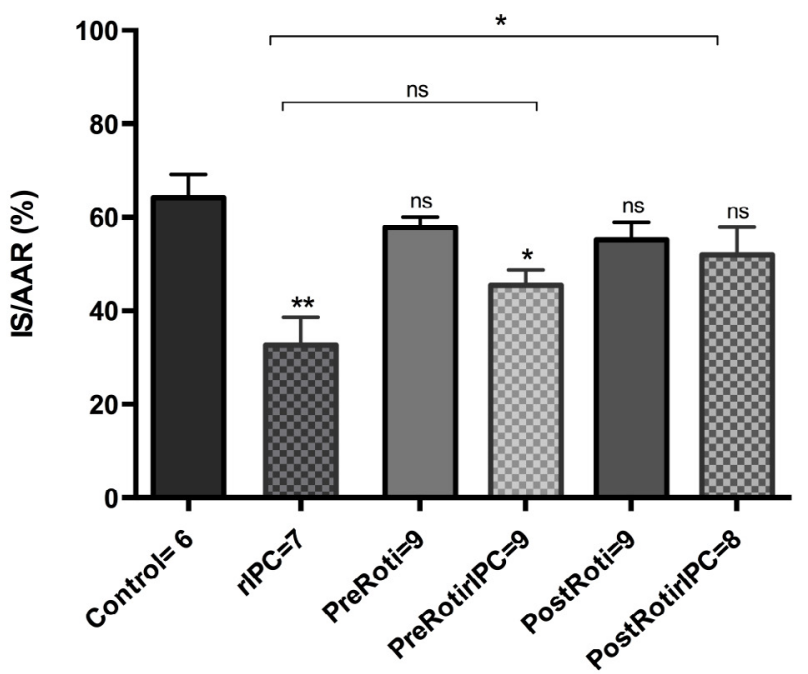

Figure 2: Infarct size: Data are presented as mean \pm SEM. Effect of rIPC and/or Rotigaptide administered before or after ischemia on infarct size (IS) as percentage of area-at-risk (AAR). NS non-significant. * $p \leq 0.05 ;{ }^{* *} p \leq 0.001$. rIPC: Remote ischemic preconditioning; PreRoti: Rotigaptide before ischemia; PreRotirlPC: Rotigaptide before ischemia+remote ischemic preconditioning; PostRoti: Rotigaptide after ischemia; PostRotirlPC: Rotigaptide after reperfusion+remote ischemic preconditioning. 
Citation: Salman R, Johnsen J, Lassen TR, Hansen RS, Bøtker HE, et al. (2017) Effects of Rotigaptide and RIC on Ischemia Reperfusion Injury in the In Vitro Rabbit Heart. Cardiovasc Pharm Open Access 6: 209. doi: 10.4172/2329-6607.1000209

Page 4 of 6

\begin{tabular}{|c|c|c|c|c|c|c|}
\hline & \multirow{2}{*}{$\begin{array}{l}\text { Baseline } \\
11 \mathrm{~min}\end{array}$} & \multirow{2}{*}{$\begin{array}{l}\text { Rotigaptide } \\
-1 \mathrm{~min}\end{array}$} & \multirow{2}{*}{ Ischemia } & \multicolumn{3}{|c|}{ Reperfusion } \\
\hline & & & & $10 \mathrm{~min}$ & $40 \mathrm{~min}$ & $120 \mathrm{~min}$ \\
\hline \multicolumn{7}{|l|}{ LVDP (mm Hg) } \\
\hline CON & $103 \pm 7$ & $108 \pm 5$ & \multirow{6}{*}{-} & $17 \pm 3$ & $28 \pm 4$ & $24 \pm 4$ \\
\hline rIPC & $121 \pm 5$ & $121 \pm 6$ & & $22 \pm 5$ & $34 \pm 7$ & $32 \pm 7$ \\
\hline PreRoti & $102 \pm 4$ & $104 \pm 4$ & & $14 \pm 3$ & $20 \pm 2$ & $16 \pm 3$ \\
\hline PreRotirlPC & $113 \pm 6$ & $118 \pm 6$ & & $13 \pm 3$ & $25 \pm 2$ & $21 \pm 3$ \\
\hline PostRoti & $117 \pm 4$ & $119 \pm 4$ & & $9 \pm 2$ & $21 \pm 3$ & $20 \pm 3$ \\
\hline PostRotirlPC & $108 \pm 6$ & $105 \pm 6$ & & $12 \pm 2$ & $20 \pm 4$ & $20 \pm 4$ \\
\hline \multicolumn{7}{|c|}{ RPP (BPM x mm Hg) } \\
\hline CON & $21406 \pm 1664$ & $22477 \pm 796$ & \multirow{6}{*}{-} & $2915 \pm 453$ & $5160 \pm 644$ & $4285 \pm 728$ \\
\hline rIPC & $22047 \pm 1506$ & $21263 \pm 1259$ & & $3684 \pm 936$ & $6371 \pm 1302$ & $5361 \pm 1254$ \\
\hline PreRoti & $22250 \pm 747$ & $21903 \pm 552$ & & $2264 \pm 494$ & $4109 \pm 438$ & $3246 \pm 543$ \\
\hline PreRotirlPC & $23584 \pm 763$ & $23984 \pm 698$ & & $2557 \pm 508$ & $4957 \pm 408$ & $3811 \pm 549$ \\
\hline PostRoti & $23777 \pm 1041$ & $23502 \pm 1085$ & & $1807 \pm 355$ & $3933 \pm 667$ & $3565 \pm 588$ \\
\hline PostRotirlPC & $22441 \pm 1556$ & $21084 \pm 1572$ & & $1869 \pm 345$ & $4175 \pm 587$ & $3746 \pm 665$ \\
\hline \multicolumn{7}{|l|}{ Heart rate (BPM) } \\
\hline $\mathrm{CON}$ & $209 \pm 12$ & $212 \pm 16$ & \multirow{6}{*}{-} & $176 \pm 16$ & $190 \pm 19$ & $186 \pm 24$ \\
\hline rIPC & $186 \pm 17$ & $179 \pm 14$ & & $181 \pm 19$ & $193 \pm 16$ & $175 \pm 16$ \\
\hline PreRoti & $220 \pm 7$ & $211 \pm 6$ & & $198 \pm 29$ & $207 \pm 7$ & $200 \pm 9$ \\
\hline PreRotirlPC & $211 \pm 9$ & $207 \pm 11$ & & $231 \pm 24$ & $202 \pm 9$ & $187 \pm 10$ \\
\hline PostRoti & $203 \pm 6$ & $197 \pm 6$ & & $218 \pm 22$ & $222 \pm 27$ & $199 \pm 13$ \\
\hline PostRotirlPC & $207 \pm 7$ & $200 \pm 8$ & & $173 \pm 16$ & $235 \pm 33$ & $192 \pm 5$ \\
\hline \multicolumn{7}{|l|}{$\mathrm{CF}(\mathrm{mL} / \mathrm{min})$} \\
\hline CON & $48 \pm 5$ & $50 \pm 3$ & \multirow{6}{*}{ - } & $40 \pm 3$ & $27 \pm 3$ & $20 \pm 2$ \\
\hline rIPC & $55 \pm 3$ & $51 \pm 2$ & & $44 \pm 3$ & $31 \pm 3$ & $24 \pm 3$ \\
\hline PreRoti & $51 \pm 2$ & $48 \pm 1$ & & $37 \pm 2$ & $28 \pm 2$ & $23 \pm 1$ \\
\hline PreRotirlPC & $52 \pm 4$ & $52 \pm 3$ & & $43 \pm 3$ & $31 \pm 4$ & $26 \pm 4$ \\
\hline PostRoti & $53 \pm 3$ & $52 \pm 3$ & & $40 \pm 3$ & $28 \pm 2$ & $23 \pm 2$ \\
\hline PostRotirlPC & $53 \pm 2$ & $50 \pm 2$ & & $43 \pm 4$ & $31 \pm 2$ & $24 \pm 2$ \\
\hline \multicolumn{7}{|c|}{$\mathrm{dP} / \mathrm{dt} \max (\mathrm{mm} \mathrm{Hg} / \mathrm{ms})$} \\
\hline $\mathrm{CON}$ & $103 \pm 7$ & $108 \pm 5$ & \multirow{6}{*}{ - } & $17 \pm 3$ & $28 \pm 4$ & $24 \pm 4$ \\
\hline rIPC & $121 \pm 5$ & $121 \pm 6$ & & $22 \pm 5$ & $34 \pm 7$ & $32 \pm 7$ \\
\hline PreRoti & $102 \pm 4$ & $104 \pm 4$ & & $13 \pm 3$ & $20 \pm 2$ & $16 \pm 3$ \\
\hline PreRotirlPC & $113 \pm 6$ & $118 \pm 6$ & & $13 \pm 3$ & $25 \pm 2$ & $21 \pm 3$ \\
\hline PostRoti & $117 \pm 4$ & $119 \pm 4$ & & $9 \pm 2$ & $22 \pm 3$ & $18 \pm 3$ \\
\hline PostRotirlPC & $108 \pm 6$ & $105 \pm 6$ & & $12 \pm 2$ & $20 \pm 4$ & $20 \pm 4$ \\
\hline
\end{tabular}

Table 1: Hemodynamic function. (rIPC: remote ischemic preconditioning; PreRoti: Rotigaptide before ischemia; PreRotirlPC: remote ischemic preconditioning + Rotigaptide before ischemia; PostRoti: Rotigaptide after reperfusion; PostRotirlPC: remote ischemic preconditioning + Rotigaptide after reperfusion; LVDP: left ventricular developed diastolic pressure; RPP: heart rate pressure product; BPM: beats per minute; CF: coronary flow; dp/dt: rate of rise of left ventricular pressure).

Rotigaptide administration intravenously as a $10 \mathrm{~min}$ bolus prior to reperfusion followed by a continuous intravenous infusion during $2 \mathrm{~h}$ of reperfusion [10]. Similarly, Haugan et al. showed that myocardial infarction induced by coronary artery ligation followed by administration of Rotigaptide during a three-week period could reduce IS in rats. Their study was conducted with three different concentrations $(1.1 \pm 0.3,16 \pm 4.5$ and $230 \pm 63 \mathrm{nM})$ of Rotigaptide and differed from our study by absence of reperfusion and thus did not investigate reperfusion injury. Compared with a vehicle group, only treatment with the intermediate dose of Rotigaptide reduced IS [11]. The results tended to respond in a bell-shaped dose-response relationship. Consequently, Rotigaptide was subsequently tested in dogs subjected to coronary occlusion in an in vivo model by Hennan and colleagues. Rotigaptide was administered in different groups receiving i.v. bolus of Rotigaptide $10 \mathrm{~min}$ before reperfusion and different concentrations throughout reperfusion $(1 \mathrm{ng} / \mathrm{kg}$ bolus $+10 \mathrm{ng} / \mathrm{kg} / \mathrm{h}$ infusion, $10 \mathrm{ng} / \mathrm{kg}$ bolus+100 ng/kg/h and $100 \mathrm{ng} / \mathrm{kg}$ bolus+1000 ng/kg/h and $1000 \mathrm{ng} /$ $\mathrm{kg}$ bolus $+10 \mathrm{ng} / \mathrm{kg} / \mathrm{h}$ ). In this study, IS reduction was dose-dependent [12]. More recently, danegaptide a mimetic of the connexin 43 targeting peptide Rotigaptide also demonstrated cardioprotective capacity in an in vivo model [20].
The discrepancy between results in our in vitro studies and those observed in previous in vivo studies may relate to the different models. First, our study was an in vitro model in which we applied acute global ischemia rather than regional ischemia. Also, species differences (rat/dogs vs. rabbits) may have been of importance. While reduced gap junction intercellular communication by gap junction uncoupler heptanol may reduce cell-to-cell propagation of hypercontracture and cell death [16,21], heptanol failed to induce cardioprotection specifically in a rabbit model of ischemia/ reperfusion injury [22]. Similarly, Rotigaptide increases atrial conduction velocity in a rabbit model of chromic volume overload induced atrial conduction velocity slowing. However, the reduction did not translate into a prevention of atrial tachyarrhythmia inducibility [23]. Together, these findings may indicate that the rabbit model is not optimal for studying the impact of Rotigaptide on ischemia reperfusion injury and arrhythmia mechanisms. Finally, we administered a single dose to reach our target concentration in the circulating buffer. Yet, we achieved circulating Rotigaptide concentrations in our in vitro model of $201 \mathrm{nmol} / \mathrm{l}$, which was within the range of $157-322 \mathrm{nmol} / \mathrm{l}$ that was previously reported to yield cardioprotection in an in vivo dog model [12]. 
The mechanism underlying the cardioprotective effect of Rotigaptide in other species $[11,12]$ is thought to involve modulation of Cx43 [24]. Its localization in the intercalated discs of the myocyte cell membrane $[25,26]$, involves not only gap junctions but also nonjunctional hemichannels. The additional presence in the cardiac mitochondria [18], favours these three positions as likely sites of action. Phosphorylation of serine residues regulates Cx43 activity associated with gap junction uncoupling during ischemia [13] while non-junctional Cx43 is involved in volume regulation [27], and contributes to development of edema during ischemia/reperfusion [28]. Inhibition of sarcolemmal Cx43 is cardioprotective [16,17]. The presence of $\mathrm{Cx} 43$ in the myocyte mitochondria [29,30], is mandatory for cardioprotection by ischemic preconditioning [31,32], by interaction with ATP-dependent potassium channels and formation of reactive oxygen species. Cardioprotection by ischemic preconditioning is associated with opening of mitochondrial $\mathrm{Cx} 43$ channels before ischemia/reperfusion [33].

The unpredictable response to Rotigaptide in various species may relate to dissimilar effect between the different sites of actions. Hence, the resultant agonist or antagonist action of connexin modulating peptides on endogenous connexins may depend on their predominant site of action [34]. During prolonged ischemia Cx43 is dephosphorylated followed by redistribution of Cx43 from the intercalated discs to the lateral cell borders [35,36], redistribution to the intercellular pool [37], and opening of hemichannels [38], which modify cardiomyocyte intercellular communication. AAP10, an unstable predecessor of Rotigaptide, seems to modulate $\mathrm{Cx} 43$ only in the intercalated discs while being inactive on $\mathrm{Cx} 43$ in the lateral cell borders [39]. Changes in the spatial distribution of $\mathrm{Cx} 43$ are observed during ischemia, including local ischemic preconditioning $[36,40]$, and is associated with improved cellular survival. The attenuating effect of conditioning by Rotigaptide may be caused by its ability to redistribute and reorganize active $\mathrm{Cx} 43$ from intercellular gap junctions. Because lateralization of $\mathrm{Cx} 43$ from the gap junction following ischemiareperfusion or modification by $\mathrm{rIPC} /$ local ischemic preconditioning $[19,41]$, are not consistent findings and because the specific impact of Rotigaptide on mitochondrial $\mathrm{Cx} 43$ channels remain unknown, the exact mechanism are not completely clarified by our study. Even though Rotigaptide per se did not change ischemia-reperfusion injury, our data indicate that a modification of gap junctional conductance, presumably by a predominant increment, clearly attenuates the cardioprotective efficacy of rIPC supporting the concept of a "spread of injury" [16].

Rotigaptide concentrations during reperfusion was significantly higher by post- than by preischemic Rotigaptide administration because the circulating buffer was changed to a Rotigaptide free buffer at onset of ischemia. Our finding that preischemic administration of Rotigaptide attenuated, while postischemic administration almost abrogated the cardioprotective effect of rIPC are consistent with the difference in Rotigaptide concentration during reperfusion, when preischemically administered Rotigaptide was effectively removed by buffer substitution at onset of ischemia. Our findings also suggest that a considerable modification of ischemia-reperfusion injury takes place during reperfusion.

The absence in change of hemodynamic recovery in our study is in accordance with previous studies testing Rotigaptide and the new analogue danegaptide [1-13,20,42-44]. Although we did not observe statistically significant changes in post-ischemic hemodynamic outcome between the different groups the pattern followed the expected responses according to infarct size reduction. The lack of statistically significant difference in end-LVDP between rIPC and controls are probably explained by relatively small group sizes.

Our study provided no mechanistic insight into the cardioprotective effect of Rotigaptide. Given the multiple phosphorylation sites [13,45], and potential intracellular actions of $\mathrm{Cx} 43$ and the lack of knowledge on the precise interaction of Rotigaptide with $\mathrm{Cx} 43$, it is not possible to define a potential target within the signal transduction cascade of cardioprotection.

In our power calculation, we anticipated an infarct size reduction by rotigaptide of $30 \%$ (from 60 to $40 \%$ of LV with a SD of $12 \%$ ), a significance level of $5 \%$ and a power of 0.80 . Although we included the required minimum of 6 animals requested by our power calculation in each study group, our study yields $80 \%$ probability of detecting a $30 \%$ infarct size reduction. While the absence of infarct size reduction is most probable, we do not definitively exclude a cardioprotective effect of rotigaptide in an in vitro rabbit model.

Rotigaptide per se did not modify ischemia-reperfusion injury in our rabbit Langendorff model. Rotigaptide attenuated the effect of rIPC indicating that modification of myocardial gap junction function could be involved in cardioprotection by rIPC.

\section{Acknowledgement}

The authors have no conflicts of interest to disclose. We thank Mrs. Anja Helveg Larsen and Mr. Casper Carlsen Elkjær for excellent technical assistance.

\section{References}

1. Sloth AD, Schmidt MR, Munk K, Kharbanda RK, Redington AN, et al. (2014) Improved long-term clinical outcomes in patients with ST-elevation myocardia infarction undergoing remote ischaemic conditioning as an adjunct to primary percutaneous coronary intervention. Eur Heart J 35: 168-175.

2. Cheung $M M H$, Kharbanda RK, Konstantinov IE, Shimizu M, Frndova $H$, et al. (2006) Randomized controlled trial of the effects of remote ischemic preconditioning on children undergoing cardiac surgery: first clinical application in humans. J Am Coll Cardiol 47: 2277-2282.

3. Hoole SP, Heck PM, Sharples L, Khan SN, Duehmke R, et al. (2009) Cardiac Remote Ischemic Preconditioning in Coronary Stenting (CRISP Stent) Study: a prospective, randomized control trial. Circulation 119: 820-827.

4. Davies WR, Brown AJ, Watson W, McCormick LM, West NEJ, et al. (2013) Remote ischemic preconditioning improves outcome at 6 years after elective percutaneous coronary intervention: the CRISP stent trial long-term follow-up. Circ Cardiovasc Interv 6: 246-2451.

5. Thielmann M, Kottenberg E, Kleinbongard P, Wendt D, Gedik N, et al. (2013) Cardioprotective and prognostic effects of remote ischaemic preconditioning in patients undergoing coronary artery bypass surgery: a single-centre randomised, double-blind, controlled trial. Lancet 382: 597-604.

6. Hausenloy DJ, Mwamure PK, Venugopal V, Harris J, Barnard M, et al. (2007) Effect of remote ischaemic preconditioning on myocardial injury in patients undergoing coronary artery bypass graft surgery: a randomised controlled trial. Lancet 370: 575-579.

7. Thielmann M, Kottenberg E, Boengler K, Raffelsieper C, Neuhaeuser M, et al. (2010) Remote ischemic preconditioning reduces myocardial injury after coronary artery bypass surgery with crystalloid cardioplegic arrest. Basic Res Cardiol 105: 657-664.

8. Bøtker HE, Kharbanda R, Schmidt MR, Bøttcher M, Kaltoft AK, et al. (2010) Remote ischaemic conditioning before hospital admission, as a complement to angioplasty, and effect on myocardial salvage in patients with acute myocardial infarction: a randomised trial. Lancet 375: 727-734.

9. Heusch G (2013) Cardioprotection: chances and challenges of its translation to the clinic. Lancet 381: 166-175.

10. Pedersen CM, Venkatasubramanian $\mathrm{S}$, Vase $\mathrm{H}$, Hyldebrandt JA, Contractor $\mathrm{H}$ et al. (2016) Rotigaptide protects the myocardium and arterial vasculature from ischaemia reperfusion injury. $\mathrm{Br} \mathrm{J}$ Clin Pharmacol 81: 1037-1045. 
Citation: Salman R, Johnsen J, Lassen TR, Hansen RS, Bøtker HE, et al. (2017) Effects of Rotigaptide and RIC on Ischemia Reperfusion Injury in the In Vitro Rabbit Heart. Cardiovasc Pharm Open Access 6: 209. doi: 10.4172/2329-6607.1000209

Page 6 of 6

11. Haugan K, Marcussen N, Kjølbye AL, Nielsen MS, Hennan JK, et al. (2006) Treatment with the gap junction modifier rotigaptide (ZP123) reduces infarct size in rats with chronic myocardial infarction. J Cardiovasc Pharmacol 47: 236-242.

12. Hennan JK, Swillo RE, Morgan GA, Keith JC, Schaub RG, et al. (2006) Rotigaptide (ZP123 ) Prevents Spontaneous Ventricular Arrhythmias and Reduces Infarct Size During Myocardial Ischemia. Reperfusion Injury in OpenChest Dogs 317: 236-243.

13. Axelsen LN, Stahlhut M, Mohammed S, Larsen BD, Nielsen MS, et al. Identification of ischemia-regulated phosphorylation sites in connexin43: A possible target for the antiarrhythmic peptide analogue rotigaptide (ZP123). J Mol Cell Cardiol 40: 790-798.

14. Ruiz MM, Garcia DD, Hofstaetter B, Piper HM, Soler SJ (1999) Propagation of cardiomyocyte hypercontracture by passage of $\mathrm{Na}(+)$ through gap junctions. Circ Res 85: 280-287.

15. Garcia DD, Ruiz MM (2000) Propagation of cell death during myocardial reperfusion. News Physiol Sci 15: 326-330.

16. Garcia DD, Inserte J, Ruiz MM, González M, Solares J, et al. (1997) Gap junction uncoupler heptanol prevents cell-to-cell progression of hypercontracture and limits necrosis during myocardial reperfusion. Circulation 96: 3579-3586.

17. Shintani IK, Uemura K, Yoshida K (2007) Hemichannels in cardiomyocytes open transiently during ischemia and contribute to reperfusion injury following brief ischemia. Am J Physiol Heart Circ Physiol 293:1714-1720.

18. Boengler K, Dodoni G, Rodriguez SA, Cabestrero A, Ruiz MM, et al. (2005) Connexin 43 in cardiomyocyte mitochondria and its increase by ischemic preconditioning. Cardiovasc Res 67: 234-244.

19. Brandenburger T, Huhn R, Galas A, Pannen BH, Keitel V, et al. (2014) Remote ischemic preconditioning preserves Connexin 43 phosphorylation in the rat heart. J Transl Med 12: 228.

20. Skyschally A, Walter B, Schultz HR, Heusch G (2013) The antiarrhythmic dipeptide ZP1609 (danegaptide) when given at reperfusion reduces myocardial infarct size in pigs. Naunyn Schmiedebergs Arch Pharmacol 386: 383-391.

21. Saltman AE, Aksehirli TO, Valiunas V, Gaudette GR, Matsuyama N, et al. (2002) Gap junction uncoupling protects the heart against ischemia. J Thorac Cardiovasc Surg 124: 371-376.

22. Gysembergh A, Kloner RA, Przyklenk K (2001) Pretreatment with the gap junction uncoupler heptanol does not limit infarct size in rabbit heart. Cardiovasc Pathol 10: 13-17.

23. Haugan K, Miyamoto T, Takeishi Y, Kubota I, Nakayama J, et al. (2006) Rotigaptide (ZP123) improves atrial conduction slowing in chronic volume overload-induced dilated atria. Basic Clin Pharmacol Toxicol 99: 71-79.

24. Clarke TC, Thomas D, Petersen JS, Evans WH, Martin PEM (2006) The antiarrhythmic peptide rotigaptide (ZP123) increases gap junction intercellular communication in cardiac myocytes and HeLa cells expressing connexin $43 . \mathrm{Br}$ J Pharmacol 147: 486-495.

25. Camelliti $P$, Green CR, Kohl P (2006) Structural and functional coupling of cardiac myocytes and fibroblasts. Adv Cardiol 42: 132-149.

26. Dhein S (1998) Gap junction channels in the cardiovascular system: pharmacological and physiological modulation. Trends Pharmacol Sci 19: 229-241.

27. Quist AP, Rhee SK, Lin H, Lal R (2000) Physiological role of gap-junctional hemichannels: Extracellular calcium-dependent isosmotic volume regulation. $J$ Cell Biol 148: 1063-1074.

28. Schulz R, Boengler K, Totzeck A, Luo Y, Garcia DD, et al. (2007) Connexin 43 in ischemic pre- and postconditioning. Heart Fail Rev 12: 261-266.

29. Boengler K, Hilfiker KD, Heusch G, Schulz R (2010) Inhibition of permeability transition pore opening by mitochondrial STAT3 and its role in myocardial ischemia/reperfusion. Basic Res Cardiol 105: 771-785.

30. Boengler K, Stahlhofen S, Sand A, Gres P, Ruiz MM, et al. (2009) Presence of connexin 43 in subsarcolemmal, but not in interfibrillar cardiomyocyte mitochondria. Basic Res Cardiol 104: 141-147.
31. Schwanke U, Konietzka I, Duschin A, Li X, Schulz R, et al. (2002) No ischemic preconditioning in heterozygous connexin43-deficient mice. Am J Physiol Heart Circ Physiol 283: 1740-1742.

32. Li X, Heinzel FR, Boengler K, Schulz R, Heusch G (2004) Role of connexin 43 in ischemic preconditioning does not involve intercellular communication through gap junctions. J Mol Cell Cardiol 36: 161-163.

33. Heinzel FR, Luo Y, Li X, Boengler K, Buechert A, et al. (2005) Impairment of diazoxide-induced formation of reactive oxygen species and loss of cardioprotection in connexin 43 deficient mice. Circ Res 97: 583-586.

34. De Vuyst E, Boengler K, Antoons G, Sipido KR, Schulz R, et al. (2011) Pharmacological modulation of connexin-formed channels in cardiac pathophysiology. Br J Pharmacol 163: 469-483.

35. Kléber AG, Rudy Y (2004) Basic mechanisms of cardiac impulse propagation and associated arrhythmias. Physiol Rev 84: 431-488.

36. Vetterlein F, Mu C, Cetegen C, Volkmann R, Schrader C, et al. (2006) Redistribution of connexin43 in regional acute ischemic myocardium : influence of ischemic preconditioning. Am J Physiol Heart Circ Physiol 291: 813-819.

37. Tansey EE, Kwaku KF, Hammer PE, Cowan DB, Federman M, et al. (2006) Reduction and redistribution of gap and adherens junction proteins after ischemia and reperfusion. Ann Thorac Surg 82: 1472-1479.

38. John S, Kondo R, Wang SY, Goldhaber JI, Weiss JN (1999) Connexin-43 Hemichannels Opened by Metabolic Inhibition. J Biol Chem 274: 236-240.

39. Jozwiak J, Dhein S (2008) Local effects and mechanisms of antiarrhythmic peptide AAP10 in acute regional myocardial ischemia: electrophysiological and molecular findings. Naunyn Schmiedebergs Arch Pharmacol 378: 459-470.

40. Daleau P, Boudriau S, Michaud M, Jolicoeur C, Kingma JG (2001) Preconditioning in the absence or presence of sustained ischemia modulates myocardial Cx43 protein levels and gap junction distribution. Can J Physiol Pharmacol 79: 371-378.

41. Jain SK, Schuessler RB, Saffitz JE (2003) Mechanisms of delayed electrica uncoupling induced by ischemic preconditioning. Circ Res 92: 1138-1144.

42. Kjølbye AL, Knudsen CB, Jepsen T, Larsen BDUE (2003) Pharmacological Characterization of the New Stable Antiarrhythmic Peptide Analog Ac-D-TyrD-Pro- D-Hyp-Gly-D-Ala-Gly-NH 2 ( ZP123 ): In Vivo and In Vitro Studies. J Pharmacol Exp Ther 306: 1191-1199.

43. Hennan JK, Swillo RE, Morgan GA, Rossman El, Kantrowitz J, et al. (2009) GAP-134 ([2S,4R]-1-[2-aminoacetyl]4-benzamidopyrrolidine-2-carboxylic acid) prevents spontaneous ventricular arrhythmias and reduces infarct size during myocardial ischemia/reperfusion injury in open-chest dogs. J Cardiovasc Pharmacol Ther 14: 207-214.

44. Kjølbye AL, Haugan K, Hennan JK, Petersen JS (2007) Pharmacologica modulation of gap junction function with the novel compound rotigaptide: promising new principle for prevention of arrhythmias. Basic Clin Pharmacol Toxicol 101: 215-230.

45. Solan JL, Lampe PD (2010) Connexin 43 Phosphorylation-Structural Changes and Biological Effects. Cancer Res 419: 261-272. 